\title{
XPS ANALYSIS OF NANOLAYER FORMED ON AISI 304L SS AFTER HIGH-VOLTAGE ELECTROPOLISHING (HVEP)
}

\author{
Krzysztof Rokosz, Tadeusz Hryniewicz, Steinar Raaen
}

Original scientific paper

In the paper, a novel process named the High-Voltage Electropolishing (HVEP) is proposed to gain the specific surface properties on the treated metallic material. The AISI 304L stainless steel as the biomaterial was used for the HVEP treatment. Another feature of this work is using a concentrated phosphoric acid solution within the copper nitrate as electrolyte. The main purpose of the HVEP processing in that kind of electrolyte was to incorporate the copper ions into the passive surface film. Such a modified surface nanolayer was studied by means of the X-ray Photoelectron Spectroscopy (XPS) to reveal the composition of the obtained film. The comparison of the numerical results, dependent on the voltage applied, was performed. Moreover, the $\mathrm{Cr} / \mathrm{Fe}$ and $\mathrm{Cu} / \mathrm{P}$ ratios were determined to show the advantages of this electrochemical HVEP treatment.

Keywords: AISI 304L SS; copper nitrate; High-Voltage Electropolishing (HVEP); phosphoric acid; XPS

XPS analiza nano sloja nastalog na AISI 304L SS nakon elektropoliranja pod visokim naponom (HVEP)

Izvorni znanstveni članak

U radu se predlaže novi postupak nazvan elektropoliranje pod visokim naponom - High-Voltage Electropolishing (HVEP) kako bi se dobila specifična svojstva površine obrađivanog metalnog materijala. Za HVEP obradu kao biomaterijal korišten je AISI 304L nehrđajući čelik. Druga karakteristika ovoga rada je primjena koncentrirane otopine fosforne kiseline kao elektrolita u bakrovom nitratu. Osnovna svrha HVEP-a u toj vrsti elektrolita bila je uključivanje bakarnih iona u pasivni površinski sloj. Takav se modificirani nanosloj analizirao primjenom X-ray Photoelectron Spectroscopy (XPS) kako bi se otkrio sastav dobivenog sloja. Učinjena je usporedba numeričkih rezultata, ovisno o primijenjenom naponu. Uz to, određeni su omjeri $\mathrm{Cr} / \mathrm{Fe}$ i $\mathrm{Cu} / \mathrm{P}$ kako bi se pokazale prednosti tog elektrokemijskog HVEP postupka.

Ključne riječi: AISI 304L SS; bakrov nitrat; elektropoliranje pod visokim naponom (HVEP); fosforna kiselina; XPS

\section{Introduction}

Austenitic stainless steels such as AISI 304L and AISI 316L, like the titanium, niobium and their alloys, have been continually used as metallic biomaterials. For several decades now, scientists have been trying to modify the metal surface layer by different types of electrochemical polishing, such as the standard electropolishing [1-8], magnetoelectropolishing [9-21] and high-current density electropolishing [22-26]. The electrochemical polishing processes performed under different conditions allow creating passive layers of different chemical compositions [11-14] as well as different mechanical [15-17] and corrosion [18-21] properties. In recent decades also the ways of modifying the passive layers on the treated parts were revealed in view of getting a variety of specific surface properties concerning the wettability, biocompatibility, etc. [21]. For these purposes, the magnetoelectropolishing MEP and high-current density electropolishing HDEP were developed.

In the presented study, a new process destined to the biomaterials treatment, called the High-Voltage Electropolishing (HVEP), is proposed. The Authors present the XPS analysis of the passive surface layer formed on AISI 304L stainless steel, obtained after this novel High-Voltage Electropolishing. The proposed method is similar to the Plasma Electrolytic Oxidation PEO (known also as the Micro Arc Oxidation) [27-32], which is mostly used for the electrochemical treatment of titanium, niobium, zirconium, tantalum and their alloys. These materials undergo electropolishing up to about $80 \mathrm{~V}$ and plasma is created under higher voltages, say $180 \mathrm{~V}$ and above. A micrometer-thick porous layer is formed under these PEO treatments at higher voltages.
Unfortunately, there are no related studies concerning electrochemical treatment of stainless steels under so high voltages. Moreover, this film formed after the HVEP treatment is much thinner and solid, not porous. That fact decided on the study method proposed for this work. In this case also, the Authors would like to avoid that $P E O$ name for the stainless steel electrochemical treatment. Experimental results obtained and presented in this paper are probably unique in this kind of electrochemical treatment. In this study our aim is to characterize the passive film formed on AISI 304L SS after the treatment under the voltage of $450 \mathrm{~V}$, with the process named as the High-Voltage Electropolishing HVEP.

Another important feature of this work is using the concentrated phosphoric acid solution within the copper nitrate as an electrolyte. The main aim of the HVEP processing in that solution is to incorporate the copper ions into the passive surface layer. Due to the germicidal properties of copper [34-35] it is a very important task to gain the biomaterials with such modified surface layer.

\section{Method \\ 2.1 HVEP conditions}

The High-Voltage Electropolishing HVEP was performed at two voltages of $180 \mathrm{~V}$ and $450 \mathrm{~V}$, consecutively, to compare these results with the ones obtained after electropolishing at the voltage of $14 \mathrm{~V}$ applied as a reference. The HVEP treatment time was 3 minutes. Here, the experiment performed under voltage of $14 \mathrm{~V}$, which is not a high-voltage, was used just for a comparison only. The $304 \mathrm{~L}$ steel samples (cold-rolled steel, as received) were not treated mechanically before the HVEP; they were only cleaned by acetone. After the HVEP treatment, samples were rinsed with distilled water 
and dried in air. At this primary stage, two to three samples were used each time for the studies.

Another important change is the electrolyte composition used. For the studies, a mixture of the $500 \mathrm{ml}$ concentrated orthophosphoric acid $(98 \mathrm{~g} / \mathrm{mol})$ with $150 \mathrm{~g}$ of copper nitrate electrolytes by volume, were used. For each run, the electrolytic cell made of glass was used, containing up to $500 \mathrm{dm}^{3}$ of the electrolyte solution. The detailed chemical composition of the material used for the studies was given in our earlier paper [24]. The samples of AISI 304L stainless steel were cut off from a coldrolled metal sheet after the plate rolling so that the austenitic structure was retained. They were prepared in the form of rectangular specimens of dimensions $30 \times 5$ $\mathrm{mm}$ cut off from the metal sheet $1 \mathrm{~mm}$ thick. They were traditionally cleaned before the HVEP treatment, then rinsed with distilled water and dried in air.

\subsection{XPS studies}

The XPS measurements were performed on the SCIENCE SES 2002 instrument using a monochromatic (Gammadata-Scienta) Al K(alpha) ( $h v=1486.6 \mathrm{eV}) \mathrm{X}$ ray source $(18.7 \mathrm{~mA}, 13.02 \mathrm{kV})$. The scans' analyses were carried out with an analysis area of $1 \times 3 \mathrm{~mm}$ and pass energy of $500 \mathrm{eV}$ with the energy step $0.2 \mathrm{eV}$ and the step time $200 \mathrm{~ms}$. The binding energy of the spectrometer has been calibrated by the position of the Fermi level on a clean metallic sample. The power supplies were stable and of high accuracy. The experiments were carried out in an ultra-high-vacuum system with a base pressure of about $6 \times 10^{-8} \mathrm{~Pa}\left(6 \times 10^{-10} \mathrm{mbar}\right)$. The XPS spectra were recorded in normal emission. For the XPS analyses the CasaXPS 2.3.14 software (Shirley background type), with data presented in references [35-40], was used. Maximum depth of XPS analysis is about $10 \mathrm{~nm}$ and it is most likely equal to the thickness of the passive film obtained and studied.

\section{Results}

In Fig. 1, the high resolution XPS spectra of the passive layer formed on the austenitic AISI 304L stainless steel after the High-Voltage Electropolishing (HVEP) in the electrolyte consisting of $500 \mathrm{ml} \mathrm{H}_{3} \mathrm{PO}_{4}$ with the addition of $150 \mathrm{~g}$ of $\mathrm{Cu}\left(\mathrm{NO}_{3}\right)_{2}$, are displayed. The highest and the lowest chromium compound signals after the electrochemical treatments at $14 \mathrm{~V}$ and $180 \mathrm{~V}$, respectively, were recorded. In the case of iron, the highest compound peak was noted after the polishing at $14 \mathrm{~V}$ and the smallest one after the treatment at $180 \mathrm{~V}$.

The binding energy of the phosphorus peak amounting in the range of 133-134 eV and the oxygen peak with the binding energy of about $532 \mathrm{eV}$ for all the treatments can suggest that in the passive layers there are phosphates of chromium and/or iron and/or copper. However, it should be noted that a part of oxygen is bonded with carbon, and that should be treated as a contamination. Herewith one should add that the measured layer consists of two sub-layers: the outer one, i.e. mostly contamination layer (carbon-oxygen compounds, coming e.g. from cleaning or from air, $\mathrm{CO}_{2}$ ) and the inner one, i.e. pure passive film (chromium-ironnickel compounds).

The chemical composition is given by the fitting of curves. Concerning the accuracy or uncertainties, the core level peak positions may typically be determined to within $0.1 \mathrm{eV}$. The energy scale of the instrument has been calibrated to within $<0.05 \mathrm{eV}$.

For determination of chemical composition of the passive layer, only iron, chromium, copper and phosphorus were taken into account. On the basis of the data presented in Fig. 1, the chemical compositions of the passive layers, formed on AISI 304L SS after the HVEP treatment, were calculated, what is shown in Tab. 1. One can easily notice that the highest amounts of copper (4.4 at $\%$ ) and iron (5.4 at $\%$ ) in the passive layer were obtained after the electrochemical high-voltage polishing at $450 \mathrm{~V}$, while the maximum of phosphorus (82.6 at\%) and chromium (17.3 at\%) was noted after the treatment at $180 \mathrm{~V}$ and $14 \mathrm{~V}$, respectively. The binding energies $935.2 \mathrm{eV}$ and $943.3 \mathrm{eV}$ for the copper spectra $\mathrm{Cu} 2 \mathrm{p}$ clearly show that the copper most likely is on the second stage of oxidation. On the basis of $\mathrm{Cu} 2 \mathrm{p}_{3 / 2}$ sat it may be concluded that most likely the copper will be bonded oxide forming $\mathrm{CuO}$ [41].

Table 1Results of Fe $2 \mathrm{p}_{3 / 2}, \mathrm{Cr} 2 \mathrm{p}_{3 / 2}, \mathrm{Cu} 2 \mathrm{p}$ and $\mathrm{P} 2 \mathrm{p}$ fitting (in at $\%$ )

\begin{tabular}{|c|c|c|c|c|}
\hline Voltage, $\mathrm{V}$ & $\mathrm{Fe}$ & $\mathrm{Cr}$ & $\mathrm{P}$ & $\mathrm{Cu}$ \\
\hline 14 & 4.4 & 17.3 & 76.3 & 2.0 \\
\hline 180 & 3.2 & 10.8 & 82.6 & 3.4 \\
\hline 450 & 5.4 & 11.4 & 78.8 & 4.4 \\
\hline
\end{tabular}

In Fig. 2, the fitted high resolution XPS results of $\mathrm{Fe} 2 \mathrm{p}_{3 / 2}$ of the passive layer formed on AISI 304L SS after the High-Voltage Electropolishing in the electrolyte containing $\mathrm{H}_{3} \mathrm{PO}_{4}$ within $\mathrm{Cu}\left(\mathrm{NO}_{3}\right)_{2}$, are presented. In all the spectra, there are visible signals coming from the metallic iron $\left(\mathrm{Fe}^{0}\right)$, which most likely is derived from the matrix. It should be also pointed out that the signals from the iron compounds derived from the same depth of the passive layer are growing with the increasing of the voltage applied. This may mean that the passive layer has been more enriched in the iron compounds after the electrochemical treatment at $450 \mathrm{~V}$ than that after polishing at the lower voltages, i.e. $14 \mathrm{~V}$ and/or $180 \mathrm{~V}$. The binding energies of the iron compound peaks for the HVEP at $14 \mathrm{~V}, 180 \mathrm{~V}$ and $450 \mathrm{~V}$ amount to $712.7 \mathrm{eV}$ $(\mathrm{FWHM}=3), 712.1(\mathrm{FWHM}=3)$, and $712.4(\mathrm{FWHM}=3.6)$, respectively. For the electrochemical polishing at $14 \mathrm{~V}$, on the basis of the binding energy for the iron compounds, i.e. $712.7 \mathrm{eV}$, it can be concluded that the signal originated mainly from the iron phosphates $\left(\mathrm{Fe}_{3} \mathrm{PO}_{4}\right)_{2}$ and $\mathrm{FePO}_{4}$. However, it should be taken into account that the full width at the half maximum (FWHM) is very broad, what may indicate, especially in the lower binding energies, the iron oxides and hydroxides occur. The main iron compound peak obtained from the surface treated at $180 \mathrm{~V}$ has the binding energy equalling 712.1 $\mathrm{eV}$ with $\mathrm{FWHM}=3$. This binding energy shift into the smaller energy can be interpreted that here a higher amount of iron III oxides and/or hydroxides bonded with iron phosphates appear. 

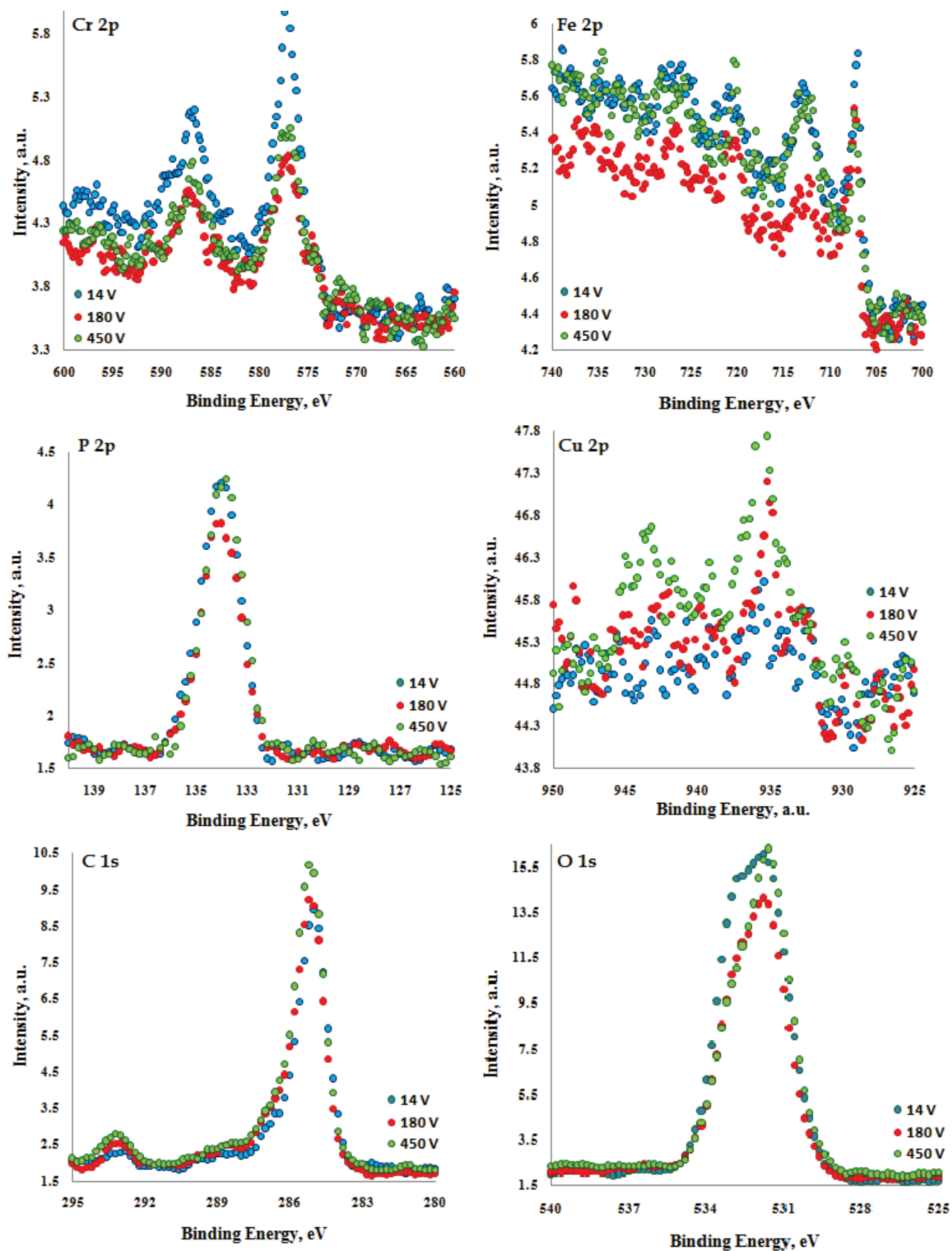

Figure 1 XPS results (Cr 2p, Fe 2p, P 2p, Cu 2p, C 1s, O1s) of the passive layer formed on AISI 304L SS after High-Voltage Electropolishing (HVEP) in the electrolyte containing $\mathrm{H}_{3} \mathrm{PO}_{4}$ within $\mathrm{Cu}\left(\mathrm{NO}_{3}\right)_{2}$

After the electrochemical polishing at the highest voltage applied, i.e. $450 \mathrm{~V}$, the passive layer was formed, from which the iron compounds signal described by one peak is equal to $712.4 \mathrm{eV}$ with $\mathrm{FWHM}=3.6$. Similar as for the HVEP treatment at $180 \mathrm{~V}$, the binding energy is in the range where the oxides, hydroxides as well as phosphates of iron have been detected. Knowing that after this HVEP treatment at $450 \mathrm{~V}$ the amount of iron is the highest one from all values received, together with a smaller amount of phosphorus than after the electropolishing at $180 \mathrm{~V}$, it can be concluded that in the passive layer, besides iron phosphates, also oxides and hydroxides of iron II and III have occurred.

In Fig. 3, the fitted high resolution XPS results of $\mathrm{Cr}$ $2 p_{3 / 2}$ of the passive layer formed on AISI 304L SS after the High-Voltage Electropolishing HVEP in the electrolyte containing $\mathrm{H}_{3} \mathrm{PO}_{4}$ within $\mathrm{Cu}\left(\mathrm{NO}_{3}\right)_{2}$, are displayed. In all the presented spectra the signals from metallic chromium $\left(\mathrm{Cr}^{0}\right)$ are visible. Also in all spectra at the binding energy of $574.2 \mathrm{eV}$ the signals from the metallic chromium $\left(\mathrm{Cr}^{0}\right)$ were found, what can be considered as the matrix signals. The highest metallic signal $\left(18 \%\right.$ of the whole detected chromium $\mathrm{Cr} 2 \mathrm{p}_{3 / 2}$ signal) was recorded for the passive layer obtained by the electrochemical polishing at $180 \mathrm{~V}$ while the smallest one $(7.9 \%)$ was noted for the HVEP treatment at $450 \mathrm{~V}$. Herewith the amount of carcinogenic chromium VI was the lowest one, that is $1.34 \mathrm{at} \%$ of the whole detected chromium $\mathrm{Cr} 2 \mathrm{p}_{3 / 2}$ signal after the treatment at $450 \mathrm{~V}$, and the highest one $(4.6 \mathrm{at} \%)$ after the treatment at $14 \mathrm{~V}$. The lowest energy corresponds to the metal part. Always with increasing of binding energy also the oxidation stage of the element increases [3, 7, 17, 27-32]. The $\mathrm{Cr}^{6+}$ can be found at the binding energy of about $579 \mathrm{eV}$ and a little bit over. 

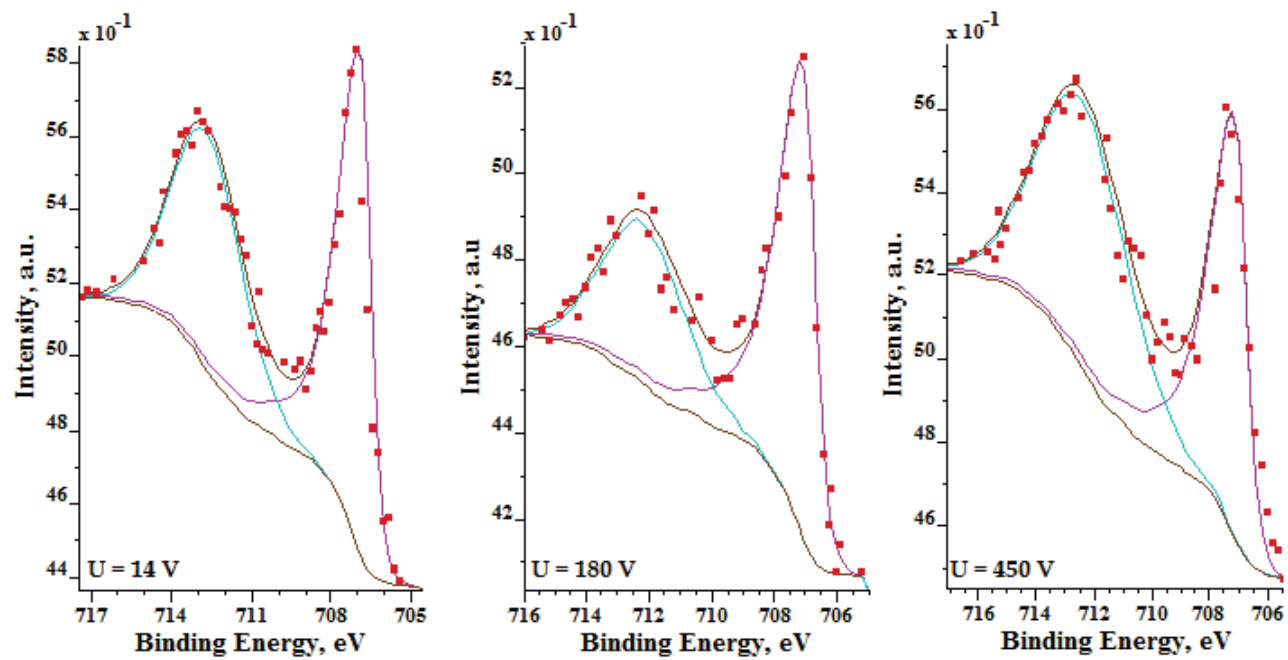

Figure $2 \mathrm{Fe} 2 \mathrm{p}_{3 / 2}$ XPS results of the passive layer formed on AISI 304L SS after the High-Voltage Electropolishing in the electrolyte containing $\mathrm{H}_{3} \mathrm{PO}_{4}$ within $\mathrm{Cu}\left(\mathrm{NO}_{3}\right)_{2}$
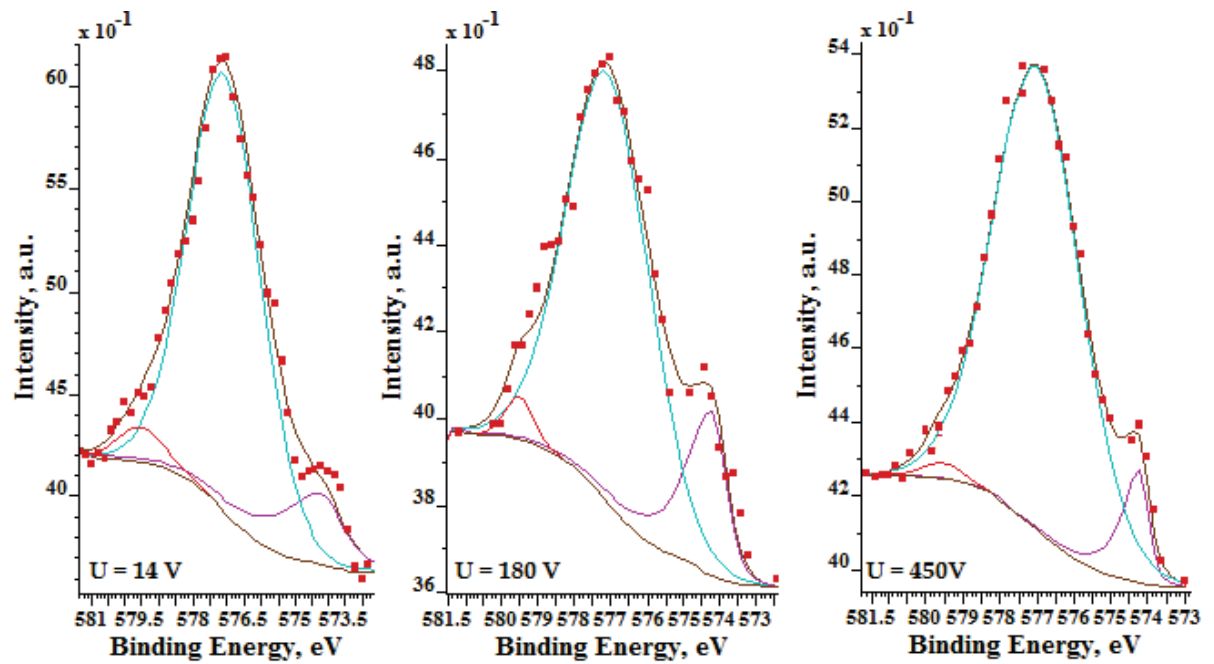

Figure $3 \mathrm{Cr} 2 \mathrm{p}_{3 / 2}$ XPS results of the passive layer formed on AISI 304L SS after the High-Voltage Electropolishing in the electrolyte containing $\mathrm{H}_{3} \mathrm{PO}_{4}$ within $\mathrm{Cu}\left(\mathrm{NO}_{3}\right)_{2}$
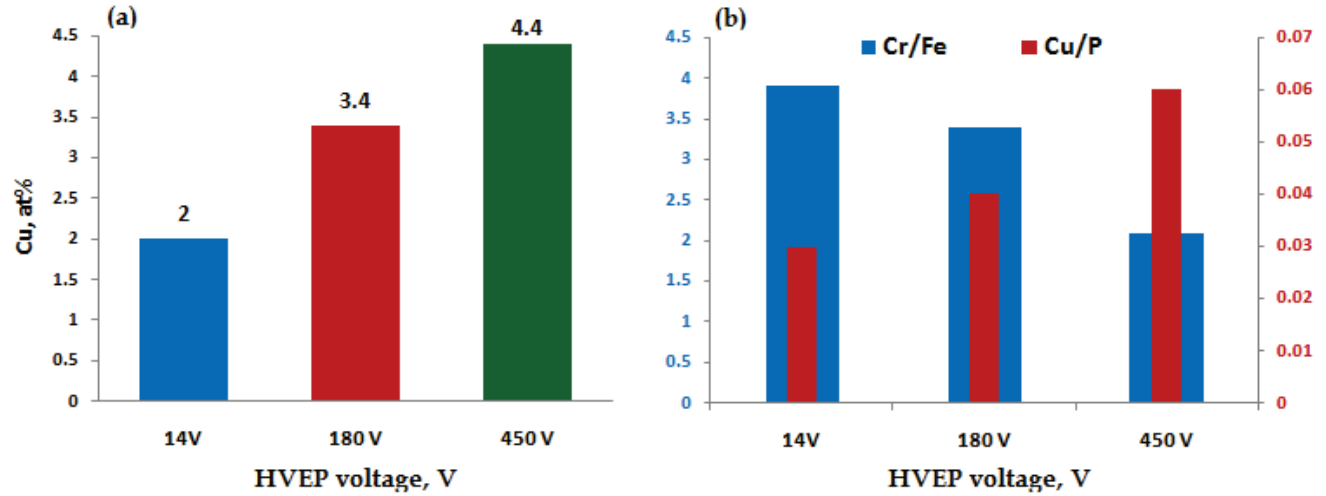

Figure 4 Bar graphs describing the percentage of copper by at $\%$ in the surface passive layer formed on AISI 304L SS after the High-Voltage Electropolishing (HVEP) in the electrolyte containing $\mathrm{H}_{3} \mathrm{PO}_{4}$ within $\mathrm{Cu}\left(\mathrm{NO}_{3}\right)_{2}$ (a), as well as the chromium-to-iron $(\mathrm{Cr} / \mathrm{Fe}$ by at\%) and copper-tophosphorus $(\mathrm{Cu} / \mathrm{P}$ by at $\%)$ ratios (b)

In Fig. 4, the bar graphs describing the percentage of copper in the surface passive nanolayer formed on AISI 304L SS after the High-Voltage Electropolishing in the electrolyte containing $\mathrm{H}_{3} \mathrm{PO}_{4}$ within $\mathrm{Cu}\left(\mathrm{NO}_{3}\right)_{2}$ as well as the chromium-to-iron $(\mathrm{Cr} / \mathrm{Fe})$ and copper-tophosphorus $(\mathrm{Cu} / \mathrm{P})$ ratios, are shown. In Fig. $4 \mathrm{a}$, one may notice that the higher amount of copper can be incorporated into the passive layer by the HVEP at $450 \mathrm{~V}$. The copper amount is over two times higher than that noted for the standard electropolishing at $14 \mathrm{~V}$.
Additionally, the mathematical formula describing the percentage amount of copper in the passive layer as a function of the processing voltage was found:

$\mathrm{Cu}(\mathrm{at} \%)=1.2 \cdot U+0.866\left(R^{2}=0.99\right)$

where $U$ corresponds with the HVEP voltage. The mathematical formula is only a way of mathematical description. Due to the possibility of error, the linear function was used to describe the experimental data and 
given the very large adjustment $\left(R^{2}\right.$ over 90\%) [33], where: $R^{2}$ - coefficient of determination (it shows how well the data are fitted to a statistical model); $R$ - linear correlation coefficient (it shows the strength and the direction of a linear relationship between two variables).

In Fig. 4b, there are presented two ratios, i.e. the chromium-to-iron ratio $(\mathrm{Cr} / \mathrm{Fe})$ and the copper-tophosphorus $(\mathrm{Cu} / \mathrm{P})$ ratio. For the standard polishing at $14 \mathrm{~V}$ the $\mathrm{Cr} / \mathrm{Fe}$ ratio is the highest (3.9) while the $\mathrm{Cu} / \mathrm{P}$ ratio is the smallest one $(0.03)$. For the electrochemical treatment at $450 \mathrm{~V}$ the situation is opposite, i.e. the $\mathrm{Cr} / \mathrm{Fe}$ ratio is the smallest (2.1) and the $\mathrm{Cu} / \mathrm{P}$ ratio is the highest (0.06). From this it follows that after the HVEP polishing the passive layer contains less amount of the carcinogenic chromium on the sixth stage of oxidation and more bactericidal copper. Additionally, the Authors propose two mathematical equations, (1) and (2), describing the two ratios as a function of the treatment voltage ( $U$ in the equations corresponds to the HVEP voltage):

$\mathrm{Cr} / \mathrm{Fe}(\mathrm{at} \%)=-0.9 \cdot U+4.933\left(R^{2}=0.94\right)$

$\mathrm{Cu} / \mathrm{P}(\mathrm{at} \%)=0.015 \cdot U+0.013\left(R^{2}=0.96\right)$

\section{Conclusions}

The studies carried out allow drawing several meaningful conclusions, as follows:

- High-Voltage Electropolishing (HVEP) of AISI 304L $\mathrm{SS}$ allows to incorporate copper ions into the passive nanolayer

- the higher treatment voltage, the higher amount of copper into the passive nanolayer is introduced

- the higher treatment voltage, the higher copper-tophosphorus $(\mathrm{Cu} / \mathrm{P})$ ratio is gained

- the higher treatment voltage, the smaller chromiumto-iron $(\mathrm{Cr} / \mathrm{Fe})$ ratio is obtained

- the higher treatment voltage, the smaller carcinogenic chromium VI appears in the passive nanolayer.

Moreover, one may also notice that:

- incorporated copper into the passive layer is mostly on the second stage of oxidation forming $\mathrm{CuO}$

- the passive layer consists mainly of the iron phosphates and iron, copper oxides and/or hydroxides.

\section{Acknowledgements}

The BerlinerLuft company, especially Bogusław Lackowski, $\mathrm{PhD}$, is acknowledged for delivering the 304L SS samples for the studies.

\section{References}

[1] Hryniewicz, T. On Discrepancies between Theory and Practice of Electropolishing, Materials Chemistry and Physics. // 15, 2(1986), pp. 139-154. https://doi.org/10.1016/0254-0584(86)90119-7

[2] Hryniewicz, T. Concept of microsmoothing in the electropolishing process. // Surface\& Coatings Technology, 64, 2(1994), pp. 75-80. https://doi.org/10.1016/S0257-8972(09)90006-8

[3] Rokicki, R.; Hryniewicz, T. Enhanced oxidation-dissolution theory of electropolishing. // Transactions Inst. Met. Finish., 90, 4(2012), pp.188-196 https://doi.org/10.1179/0020296712Z.00000000031
[4] Sowa, M.; Kazek-Kesik, A.; Krzakala, A.; Socha, R. P.; Dercz, G. Michalska, J.; Simka, W. Modification of niobium surfaces using plasma electrolytic oxidation in silicate solutions. // Journal of Solid State Electrochemistry, 18, 11(2014), pp. 3129-3142. https://doi.org/10.1007/s10008-013-2341-7

[5] Hryniewicz, T.; Rokosz, K.; Zschommler, S. H. R. SEM/EDX and XPS studies of niobium after electropolishing. // Applied Surface Science, 263, (2012), pp. 357-361. https://doi.org/10.1016/j.apsusc.2012.09.060

[6] Sowa, M.; Kazek-Kęsik, A.; Socha, R. P.; Dercz, G.; Michalska, J.; Simka, W. Modification of tantalum surface via plasma electrolytic oxidation in silicate solutions. // Electrochimica Acta, 114, (2013), pp. 627-636. https://doi.org/10.1016/j.electacta.2013.10.047

[7] Hryniewicz, T.; Rokicki, R.; Rokosz, K. Co-Cr alloy corrosion behaviour after electropolishing and "magnetoelectropolishing" treatments. // Materials Letters, 62, 17-18(2008), pp. 3073-3076. https://doi.org/10.1016/j.matlet.2008.01.130

[8] Rokosz, K.; Hryniewicz, T.; Raaen, S.; Valiček, J. SEM/EDX, XPS, corrosion and surface roughness characterization of AISI 316L SS after electrochemical treatment in concentrated HNO3. // Tehnicki VjesnikTechnical Gazette, 22, 1(2015), pp. 125-131. https://doi.org/10.17559/TV-20140211130812

[9] Rokicki, R.; Haider, W.; Hryniewicz, T.Influence of Sodium Hypochlorite Treatment of Electropolished and Magnetoelectropolished Nitinol Surfaces on Adhesion and Proliferation of MC3T3 Pre-osteoblast Cells. // Journal of Materials Science: Materials in Medicine, 23, (2012), pp. 2127-2139. https://doi.org/10.1007/s10856-012-4696-1

[10] Hryniewicz, T.; Rokosz, K. Polarization Characteristics of Magnetoelectropolishing Stainless Steels. // Materials Chemistry and Physics, 122, 1(2010), pp.169-174. https://doi.org/10.1016/j.matchemphys.2010.02.055

[11] Hryniewicz, T.; Konarski, P.; Rokosz, K.; Rokicki, R. SIMS analysis of hydrogen content in near surface layers of AISI 316L SS after electrolytic polishing under different conditions. // Surface and Coatings Technology, 205, 1718(2011), pp. 4228-4236. https://doi.org/10.1016/j.surfcoat.2011.03.024

[12] Rokosz, K.; Simon, F.; Hryniewicz, T.; Rzadkiewicz, S. Comparative analysis of passive layers composition on AISI 304L SS after standard and high-current density electropolishing. // Surface and Interface Analysis, 47, 1(2015), pp. 87-92. https://doi.org/10.1002/sia.5676

[13] Rokosz, K.; Hryniewicz, T. XPS measurements of LDX 2101 duplex steel surface after magnetoelectropolishing. // International Journal of Materials Research, 104, 12(2013), pp. 1223-1232. https://doi.org/10.3139/146.110984

[14] Rokosz, K.; Hryniewicz, T.; Raaen, S. Characterization of passive film formed on AISI 316L Stainless Steel after Magnetoelectropolishing in a Broad Range of Polarization Parameters. // Steel Research International, 83, 9(2012), pp. 910-918. https://doi.org/10.1002/srin.201200046

[15] Hryniewicz, T.; Rokosz, K.; Valiček, J.; Rokicki, R. Effect of magnetoelectropolishing on nanohardness and Young's modulus of titanium biomaterial. // Materials Letters, 83, (2012), pp. 69-72. https://doi.org/10.1016/j.matlet.2012.06.010

[16] Hryniewicz, T.; Rokosz, K.; Rokicki, R.; Prima, F. Nanoindentation and XPS Studies of Titanium TNZ Alloy after Electrochemical Polishing in a Magnetic Field. // Materials, 8, 1(2015), pp. 205-215. https://doi.org/10.3390/ma8010205

[17] Hryniewicz, T.; Rokosz, K. Investigation of selected surface properties of AISI 316L SS after magnetoelectropolishing. // Materials Chemistry and Physics, 123, 1(2010), pp. 47-55. 
https://doi.org/10.1016/j.matchemphys.2010.03.060

[18] Hryniewicz, T.; Rokicki, R.; Rokosz, K. Corrosion and surface characterization of titanium biomaterial after magnetoelectropolishing. // Surface \& Coatings Technology, 203, 10-11(2009), pp. 1508-1515. https://doi.org/10.1016/j.surfcoat.2008.11.028

[19] Hryniewicz, T.; Rokosz, K. Corrosion resistance of magnetoelectropolished AISI 316L SS biomaterial. // AntiCorrosion Methods and Materials, 61, 2(2014), pp. 57-64. https://doi.org/10.1108/ACMM-03-2013-1249

[20] Rokosz, K.; Hryniewicz, T. Pitting corrosion resistance of AISI 316L SS in Ringer's solution after magnetoelectrochemical polishing. // Corrosion, 66, 3(2010), pp. 035004. https://doi.org/10.5006/1.3360910

[21] Rokicki, R.; Hryniewicz, T.; Pulletikurthi, C.; Rokosz, K.; Munroe, N. Towards a Better Corrosion Resistance and Biocompatibility Improvement of Nitinol Medical Devices. // Journal of Materials Engineering and Performance, 24, 4(2015), pp. 1634-1640 https://doi.org/10.1007/s11665-015-1429-x

[22] Rokosz, K.; Simon, F.; Hryniewicz, T.; Rzadkiewicz, S. XPS study of surface layer formed on AISI 316L after High-Current Density Electropolishing. // Solid State Phenomena, 227, (2015), pp. 155-158; https://doi.org/10.4028/www.scientific.net/SSP.227.155

[23] Hryniewicz, T.; Rokosz, K. Investigation of selected surface properties of AISI $316 \mathrm{~L}$ SS after magnetoelectropolishing. // Materials Chemistry and Physics, 123, 1(2010), pp. 47-55. https://doi.org/10.1016/j.matchemphys.2010.03.060

[24] Rokosz, K.; Lahtinen, J.; Hryniewicz, T.; Rzadkiewicz, S. XPS depth profiling analysis of passive surface layers formed on austenitic AISI 304L and 316L SS after HighCurrent-Density Electropolishing. // Surface and Coatings Technology, 276, (2015), pp. 516-520. https://doi.org/10.1016/j.surfcoat.2015.06.022

[25] Rokosz, K.; Hryniewicz, T.; Lukeš, J.; Šepitka, J. Nanoindentation studies and modeling of surface layers on austenitic stainless steels by extreme electrochemical treatments. // Surface and Interface Analysis, 47, 6(2015), pp. 643-647. https://doi.org/10.1002/sia.5758

[26] Rokosz, K.; Hryniewicz, T.; Rzadkiewicz, S.; Raaen, S. High-Current Density Electropolishing (HDEP) of AISI 316L SS (EN 1.4404) Stainless Steel. // Tehnicki VjesnikTechnical Gazette, 22, 2(2015), pp. 415-424 https://doi.org/10.17559/TV-20140722110711

[27] Simka, W.; Sowa, M.; Socha, R. P.; Maciej, A.; Michalska, J. Anodic oxidation of zirconium in silicate solutions. // ElectrochimicaActa, 104, (2013), pp. 518-525. https://doi.org/10.1016/j.electacta.2012.10.130

[28] Sowa, M.; Piotrowska, M.; Widziołek, M.; Dercz, G.; Tylko, G.; Gorewoda, T.; Osyczka, A. M.; Simka, W. Bioactivity of coatings formed on Ti-13Nb-13Zr alloy using plasma electrolytic oxidation. // Materials Science \& Engineering C - Materials for Biological Applications, 49, (2015), pp. 159-173. https://doi.org/10.1016/j.msec.2014.12.073

[29] Simka, W.; Socha, R. P.; Dercz, G.; Michalska, J.; Maciej, A.; Krzakala, A. Anodic oxidation of Ti-13Nb-13Zr alloy in silicate solutions. // Applied Surface Science, 279, (2013), pp. 317-323. https://doi.org/10.1016/j.apsusc.2013.04.091

[30] Rokosz. K.; Hryniewicz, T.; Raaen S. Development of plasma electrolytic oxidation for improved Ti6Al4V biomaterial surface properties. // International Journal of Advanced Manufacturing Technology, (2015). https://link.springer.com/article/10.1007/s00170-015-8086-y

[31] Rokosz, K.; Hryniewicz, T. Comparative SEM and EDX Analysis of Surface Coatings Created on Niobium and Titanium Alloys after Plasma Electrolytic Oxidation (PEO).
// Tehnicki Vjesnik-Technical Gazette, 24, 2(2017), pp. 465-472. https://doi.org/10.17559/TV-20151105101443

[32] Rokosz, K.; Hryniewicz, T.; Raaen, S. SEM, EDS and XPS Analysis of Nanostructured Coating Obtained on NiTi Biomaterial Alloy By Plasma Electrolytic Oxidation (PEO). // Tehnicki Vjesnik-Technical Gazette, 24, 1(2017), pp. 193-198. https://doi.org/10.17559/TV-20151021112657

[33] Chen, N-H.; Chung, C-J.; Chaing, C-C.; Chen, K-C.; He, JL. Antimicrobial and decorative ion-plated coppercontaining ceramic coatings. // Surface \& Coatings Technology, 236, (2013), pp. 29-35. https://doi.org/10.1016/j.surfcoat.2013.04.012

[34] Hempel, F.; Finke, B.; Zietz, C.; Bader, R.; Weltmann, K. D.; Polak, M. Antimicrobial surface modification of titanium substrates by means of plasma immersion ion implantation and deposition of copper. // Surface \& Coatings Technology, 256, (2014), pp. 52-58. https://doi.org/10.1016/j.surfcoat.2014.01.027

[35] Fairley, N. http://www.casaxps.com, (C) Casa software Ltd., (2005).

[36] CasaXPS Processing Software, CasaXPS Manual 2.3.15 Rev 1.0, Copyright (C) 2010 Casa Software Ltd, pp. 19-20.

[37] Walton, J.; Carrick, A. The Casa Cookbook-The CasaXPS User's Manual, Part 1: Recipes for XPS data proceedings. ISBN: 9780954953300, Publisher: Acolyte Science, (2009).

[38] Herrera-Gomez, A. The Peak-Shirley Background (Shirley background in overlapping peaks). Centro de Investigación y de EstudiosAvanzadosdel IPN Unidad Querétaro, Internal Report Created 8/2011, Last Update 2/2012, (14 pages).

[39] Biesinger, M. C.; Payne, B. P.; Grosvenor, A. P.; Lau, L. W. M.; Gerson, A. R.; Smart, R. St.C. Resolving surface chemical states in XPS analysis of first row transition metals, oxides and hydroxides: $\mathrm{Cr}, \mathrm{Mn}, \mathrm{Fe}, \mathrm{Co}$ and $\mathrm{Ni}$. // Applied Surface Science, 257, (2011), pp. 2717-2730. https://doi.org/10.1016/j.apsusc.2010.10.051

[40] Rokosz, K.; Hryniewicz, T.; Raaen, S. Cr/Fe ratio by XPS spectra of magnetoelectropolished AISI 316L SS fitted by Gaussian-Lorentzian shape lines. // Tehnicki VjesnikTechnical Gazette. 21, 4(2014), pp. 533-538.

[41] Wagner, C. D.; Naumkin A.V., Kraut-Vass, A.; Allison J. W.; Powell, C. J.; Rumble, J. R. Jr. NIST Standard Reference Database 20, Version 3.4, (2003), (web version) (http:/srdata.nist.gov/xps/)

\section{Authors' addresses}

Krzysztof Rokosz, DSc PhD, Assoc. Prof

Division of Bioengineering and Surface Electrochemistry Department of Engineering and Informatics Systems Faculty of Mechanical Engineering Koszalin University of Technology Racławicka 15-17, 75-620 Koszalin, Poland E-mail: rokosz@tu.koszalin.pl

\section{Tadeusz Hryniewicz, DSc PhD ME CE, Professor} (Corresponding author) Division of Bioengineering and Surface Electrochemistry Department of Engineering and Informatics Systems Faculty of Mechanical Engineering Koszalin University of Technology Racławicka 15-17, PL 75-620 Koszalin, Poland E-mail: Tadeusz.Hryniewicz@tu.koszalin.pl

\section{Steinar Raaen, PhD}

Department of Physics

Norwegian University of Science and Technology (NTNU) Realfagbygget E3-124 Høgskoleringen 5,

NO 7491 Trondheim, Norway

E-mail: steinar.raaen@ntnu.no 